\begin{abstract}
Artikkelimme keskiössä on Minna Rainion ja Mark Robertsin lyhytelokuva They Came in Crowded Boats and Trains (Suomi 2017, 20 min.), jossa menneisyyden ja nykyisyyden tapahtumat asettuvat ajan ja paikan ylittävään dialogiin. Teoksessa rinnastetaan kaksi Pohjois-Suomea koskettanutta evakkomatkaa: Lapin sodan aikaiset tapahtumat vuonna 1944 ja rajanylitys päinvastaiseen suuntaan vuonna 2015. Kysymme, mitä tämä rinnastus mahdollisesti tuottaa suhteessa historian uudelleen ymmärtämiseen ja millaista kuvaa teos luo pohjoisista ja eteläisistä pakolaisista.
\end{abstract}

Elokuvan kertojaääni toteaa: "Maksoimme paljon veneiden kuljettajille. He kiskoivat huimaavia kyytimaksuja." Kuvassa pieni ryhmä vakavailmeisiä nuoria miehiä kävelee hämärtyvässä illassa lyhdyt käsissään pitkin joen rantaa. Matkalaisia odottaa venekuski, joka heidän päästyään kyytiin työntää soutuveneen vesille. Kaukana siintää tunturin tai korkean vaaran profiili. Vene etääntyy rannasta ja kertoja jatkaa: "Monet meistä maksoivat kaikki rahansa. Meidän täytyi jättää koirat. Kun lähdimme, ne ulvoivat rannalla. Ja lapset parkuivat veneissä. Se oli sydäntäsärkevää." Puhe sekoittuu airojen ja veden ääneen. Sanoin kerrottu pakolaisuuden ja ihmiskaupan julma kytkentä rinnastuu viileään, verkkaiseen visuaaliseen kerrontaan.

Edellä sanallistettu kohtaus on ote Minna Rainion ja Mark Robertsin lyhytelokuvasta They Came in Crowded Boats and Trains (2017), joka rinnastaa kahden aikatason pakolaisten kertomukset: vuoden 1944 Lapin sodan ja vuoden 2015 tilanteen, jolloin Eurooppaan pyrki Lähi-idästä ja Pohjois-Afrikasta historiallisen suuri joukko turvapaikanhakijoita, pakolaisia $^{1}$ ja siirtolaisia. Osa vuoden 2015 pakenijoista päätyi suuntaamaan Suomeen Pohjois-Ruotsin ja Venäjän rajojen yli. Lapin sodan aikaan, vuonna 1944, pakolaisvirta kulki toiseen suuntaan: Suomesta Ruotsiin. Tuolloin Lapin alueelta evakuoitiin yli 100000 siviiliä, joista suuri osa länsinaapuriin. Pakolaiset olivat sekä lappilaisia että saamelaisia.
1 Käytämme tekstissä vaihtelevasti termejä pakolainen ja turvapaikanhakija. Tiedostamme käsitteiden käytön monimutkaisuuden: pakolainen viittaa yleisessä kielenkäytössä henkilöön, joka on lähtenyt kotimaastaan pakoon vainoa tai sotaa, tarkemmin määritellen pakolainen on henkilö, joka täyttää YK:n pakolaismääritelmän. Turvapaikanhakija taas on se, joka on hakenut turvapaikkaa, mutta ei ole vielä saanut sitä (ks. Kivikuru \& al. 2018, 8). 1940-luvun pakolaiset tai evakot eivät vielä olleet turvapaikanhakijoita, mutta 2000-luvulla kotimaastaan paenneet voivat olla statukseltaan kumpaa vain. Pakolaisuuden, turvapaikanhakijuuden ja maahanmuuttajuuden termeistä ks. myös Huttunen 2002, 14-15. 


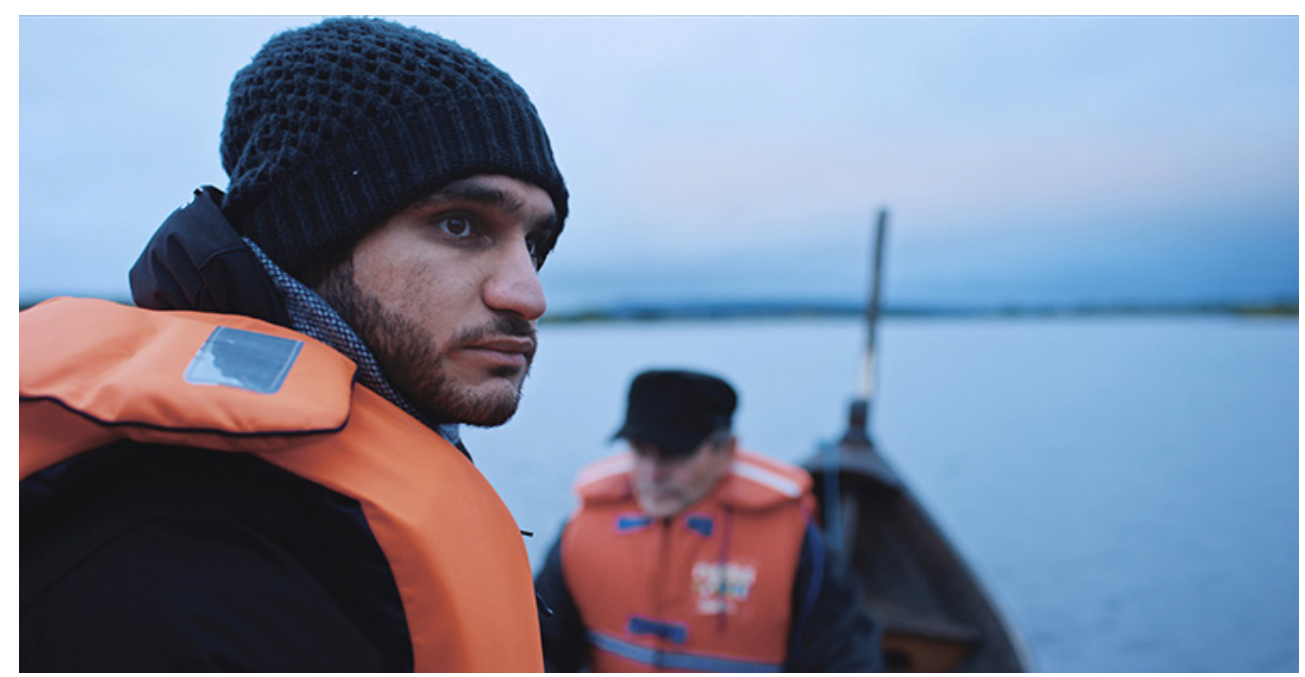

Pakolaisten vene etääntyy rannasta. Still-kuva lyhytelokuvasta They Came in Crowded Boats and Trains. Lähde: Minna Rainio ja Mark Roberts.

Tarkastelemme artikkelissamme kontekstualisoivan lähiluvun avulla taiteilijoiden tulkintaa rajanylityksistä kahtena eri aikana. Ensisijainen lähteemme on itse lyhytelokuva, jossa lomittuvat ja kerrostuvat kaksi eri aikana tapahtunutta pakolaisuuden prosessia. Käsittelemme joitakin kohtauksia, joiden kuvakerrontaa analysoimme suhteessa äänikerrontaan. Taustoittavana aineistona käytämme historiallisia lähteitä ja tutkimusta Lapin sodan ajasta, erityisesti evakuoinneista. Niin ikään kontekstualisoimme pakolaisrepresentaatioita vuoden 2015 mediatekstien avulla. Artikkelin läpikäyvänä teemana on menneisyyden (uudelleen)ymmärtäminen nykyisyyden valossa ja taiteen avulla tapahtuva mahdollinen ymmärryksen lisääminen suhteessa muiden ihmisten kohtaloihin.

They Came in Crowded Boats and Trains -elokuva alkaa kamera-ajolla, joka tuo katsojat sisään hirsitalon tupaan maaseudulla: maatalon tunnelmaan virittävät seinähirsien ohella talonpoikaiset kalusteet, räsymatot ja tiilistä muurattu takka tai uuni. Ikkunoissa on läpikuultavat verhot, joita tuuli leyhyttelee. Kun kuva avautuu hieman, nähdään nuori tummahiuksinen mies keräilemässä kukikkaaseen kangaslaukkuun arvoesineitä tuvasta. Metalliastiat kilisevät. Samalla miesääneksi tunnistettava kertojaääni alkaa puhua englannilla, jossa on voimakas aksentti: "Olimme jotenkin turtuneita, siltä minusta tuntui. Sitä ei voi oikein sanoin kuvailla." Sisään juoksee pikkutyttö, joka tarttuu laukkuun ja vie sen mennessään. Seuraavaksi näemme kuvaa talon pihapiiristä, jossa vanhempi, harmaantunut mies hautaa laukun maahan tytön seuratessa vierestä ja nuoren miehen katsoessa ikkunasta. Kertoja toteaa: "Kaikki on tuntematonta." Mies poistuu tuvasta ja kuvasta; näkemänsä ja kuulemansa perusteella katsojan on helppo tulkita tämä kodin jättämisen kuvaukseksi ja pakomatkan aluksi.

Kuva- ja äänikerronta lomittaa elokuvassa jatkuvasti eri aikatasoja toisiinsa, kerrostaa pakolaiskokemusta historiallisesti. Kuvissa esiintyvien henkilöiden vaatetus on enimmäkseen nykyaikaista. Kaikki kertojan lukemat tekstit ovat kuitenkin menneisyyden tallennusta, yli 70 vuotta sitten Pohjois-Suomesta Ruotsiin kohdistuneen pakolaisuuden kuvausta ja muistelua; otteita kirjeistä ja päiväkirjoista 70 vuoden takaa - tämä käy ilmi elokuvan lopputeksteistä, 
joissa käytetyt historialähteet mainitaan. Kuvassa esiintyvät henkilöt on mahdollista tunnistaa nykyhetken pakolaisiksi, kun heidät sijoittaa pakolaisuuden kokemusta siteeraavien tekstien tulkintakehikkoon. Heidän pohjoisessa maisemassa vaeltavat hahmonsa eroavat suomalaisuuden oletetusta valkoisuudesta ja suhteutuvat teoksen toteutusajankohdan runsaaseen pakolaisia ja turvapaikanhakijoita esittäneeseen mediakuvastoon. Elokuvan visuaalisessa kerronnassa he kulkevat samoilla seuduilla kuin vuonna 1944 kotinsa jättämään joutuneet.

Teoksen nimi They Came in Crowded Boats and Trains viittaa kulkuvälineisiin, jotka olivat osin samat vuosina 1944 ja 2015: pakomatkaa tehtiin junilla, veneillä ja pitkiä matkoja kävellen. Elokuva alkaa pakosalle lähdön kuvauksesta. Sitä seuraa koettelemuksien täyttämä taival lehmien talutuksineen, kylmässä ladossa värjöttelyineen ja veneellä tapahtuvine rajanylityksineen. Lopulta saavutaan vanhalta koulurakennukselta näyttävään vastaanottokeskukseen, jossa pakolaiset saavat apua ja voivat alkaa suuntautua kohti tulevaisuutta. Teos ei kuitenkaan esitä kronologisesti etenevää yhden perheen pakomatkaa, vaan se kuvittaa fragmentaarisesti tuokioita yhtäältä alussa esiintyvän pikkutytön elämästä ja toisaalta pienen miesjoukon pakomatkasta. Visuaalisen kerronnan rinnalla kulkee Lapin evakkojen muisteluista koostettu äänikerronta, johon sekoittuu myös luonnon- ja muita ympäristön ääniä sekä rauhallista taustamusiikkia. Kyseessä on katkelmallinen taideteos, ei dokumentaarinen elokuva eikä juonellinen tarina.

Esitämme, että Rainion ja Robertsin teos kuvaa pohjoista Suomea osin uudesta näkökulmasta. Kysymme analyysissämme, mitä kahden aikatason rinnastus taideteoksessa, mahdollisesti tuottaa pakolaisuuteen, pohjoisuuteen ja sukupuoleen liittyviin kuvastoihin. Artikkeli rakentuu viiden teeman varaan, joista jokaista käsitellään omassa alaluvussaan. Analysoimme teoksessa rakentuvia asetelmia ensinnä suhteessa historialliseen pohjoiseen pakolaisuuteen ja sen kontekstiin sekä siihen, millaista tietoa teoksen katsojalla oletetaan olevan. Mikä tai kuka on se pohjoinen pakolainen, jonka tarinaa teoksen "eteläiset" hahmot elokuvassa esittävät? Toiseksi pohdimme myös aiempaa tutkimuskirjallisuutta hyödyntäen, millaisia ongelmia kahden aikatason rinnastamiseen liittyy. Kolmantena teemana on sukupuoli; pakolaisuuteen kohdistuneet stereotypiat kiinnittyivät vuoden 2015 julkisissa keskusteluissa ja sen jälkeenkin erityisesti nuoriin miehiin. Nuoret miehet edustavat pakolaisuutta myös Rainion ja Robertsin elokuvassa. Kysymme toistaako elokuva rodullistavia ja etnistäviä mieheyden esityksiä jollakin tapaa toisin suhteessa median ja sosiaalisen median diskursseihin (ks. esim. Butler 2006; Rossi 2010, 26-27). Rainion ja Robertsin teos kiinnittää tapahtumat erityisesti pohjoisen maisemaan. Maisemaan ja paikkaan liittyy olennaisesti kuuluminen, ja Laura Huttunen (2002) onkin esittänyt kysymyksen: tuleeko uudesta maasta ja paikasta pakolaisen tai siirtolaisen koti - ja jos tulee, niin millainen? Neljänneksi teemaksi nostamme esiin tulevaisuuden ja toivon, lähtemisen ja jäämisen. Tarkastelemalla teoksen vastaanottoa artikkelin lopussa on mahdollista miettiä, voiko teos vaikuttaa katsojien käsityksiin "meisyydestä" ja toiseudesta, kuulumisesta ja ulos sulkemisesta (vrt. esim. Horsti 2019, 136). Kysymme myös, millaisia mahdollisuuksia pakolaisilla on itse määritellä omaa kuvastoaan.

Kussakin alaluvussa käymme keskustelua aiemman tutkimuskirjallisuuden kanssa ja avaamme käyttämäämme käsitteistöä tarkemmin. Keskeinen tutkimuksellinen näkökulma on kulttuurihistoriallinen: pohdimme, miten teos, aikatasoja yhdistämällä, osallistuu keskusteluun historiakulttuurista (esim. Kalela 2010; Grönholm 2010) eli siitä, millaisia tulkintoja menneestä 
tehdään, miten mennyt asettuu suhteeseen nykyisyyden kanssa ja miten menneisyyttä tuotetaan nykyisyydessä. Historiallisen tutkimuksen yhtenä tavoitteena voidaan pitää toisen ihmisen osaan asettumista ja menneisyyden kokemusten ymmärtämistä. Rainion ja Robertsin teoksen katsojakokemusten voi ajatella liittyvän juuri samastumiseen ja solidaarisuuden heräämiseen (Horsti 2019), ja toisaalta myös erojen tunnistamiseen ja solidaarisuuden tuntemiseen erilaista kohtaan.

Teoksessa menneisyyden ja nykyisyyden tapahtumat asettuvat siis ajan ja paikan rajoja ylittävään dialogiin (samantyyppisestä lähestymistavasta ks. Ahonen 2018; Horsti 2019; Wagner \& Seuferling 2020). Teos ei ole historiantutkimusta eikä dokumenttielokuva; se on taideteos, joka asettaa haasteen myös katsojalle. Rainion ja Robertsin työskentelyprosessiin liittyy kuitenkin keskeisesti taustatutkimus; taide ja tutkimus kietoutuvat heidän töissään tiiviisti yhteen. Käsittelemämme teoksen toteuttaminen liittyi Lapin yliopiston tutkimushankkeeseen Matkalla ajassa ja paikassa (2016-18; Rainio 2015, 23; Rainio 2016.)

\section{Pohjoinen pakolainen}

"Raja sodan ja rauhan maailmojen välillä oli näkyvänä Suomen ja Ruotsin yhteisellä Tornionjoella. Mutta yhtä yllättävänä ja selittämättömänä myös ajallisten tapahtumien keskellä kaikkialla pohjoisessa, missä sota äkkiä muutti ystävät vihollisiksi ja päinvastoin."

Näin kirjoitti kirjailija Jorma Etto vuonna 1977 teoksen Pohjoinen taikapiiri alkusanoissa. Kirjaan oli koottu muisteluksia vuosilta 1944-1945: ajalta, jolloin yli 100000 pohjoisen asukasta joutui lähtemään kotiseudultaan evakkoon. Millainen kulttuurinen muisti ja kuvasto on rakentunut pohjoissuomalaisen evakkouden ja suomalaisen pakolaisuuden ympärille, ja miten Rainion ja Robertsin teos asettuu suhteessa siihen? Entä pitääkö katsojan tuntea Suomen ja erityisesti Lapin historiaa osatakseen lukea teokseen sisältyviä merkityksiä?

Lapin sota on ollut pitkään marginaalissa niin kansallisessa sotien muistamisessa ja muistelussa kuin myös tutkimuksen piirissä. Jälleenrakennuskauden tutkimus on paljolti keskittynyt esimerkiksi Karjalan siirtoväestön asuttamista koskeviin kysymyksiin, ja mielikuva evakosta onkin ensisijaisesti

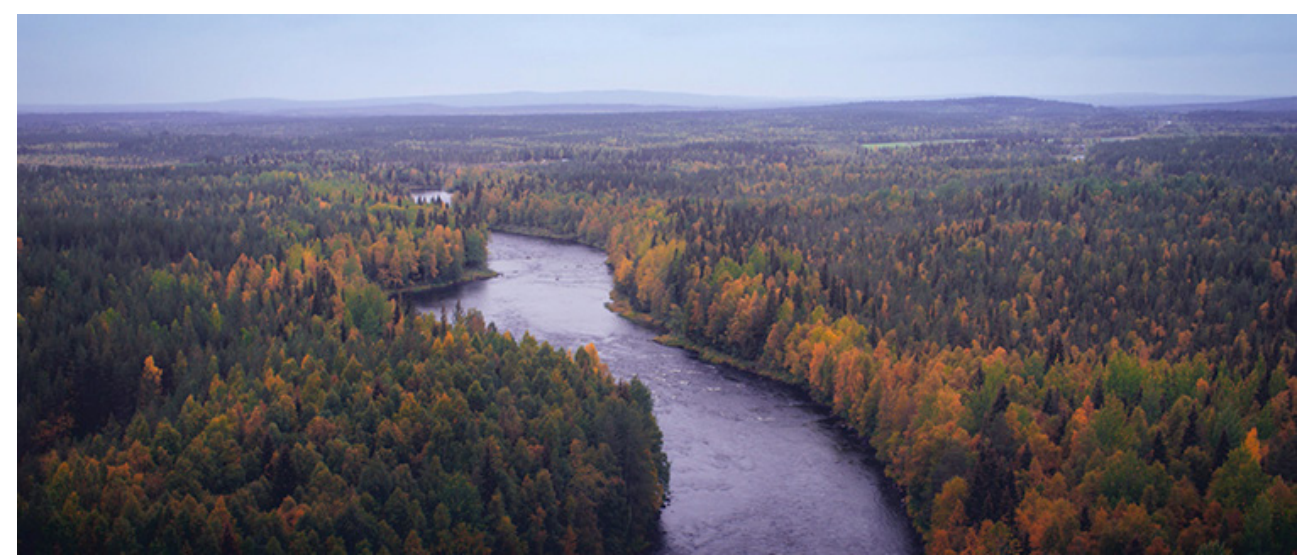

Rajajoki erottaa ja yhdistää. Pohjoinen maisema on rajan molemmilla puolilla samanlainen. Lähde: Minna Rainio ja Mark Roberts. 
Karjalan evakko - ei Sallan tai Petsamon asukas (Tuominen \& Löfgren 2018, 27). They Came in Crowded Boats and Trains sijoittaa sanallisessa ja visuaalisessa kerronnassaan kuitenkin sekä historialliset evakot että nykypakolaiset nimenomaan Lapin maisemiin, rajajoelle ja rajapisteeseen, jossa heitä tutkitaan, tarkastetaan ja kontrolloidaan. Kuvallista kerrontaa ja vuodenaikojen mukaan vaihtuvia maisemia voi toki tulkita myös jonkinlaisena "yleissuomalaisena" evakkouden ympäristönä. Elokuvan estetiikka kiinnittyy voimakkaasti kansallismaiseman kuvausperinteeseen ja alleviivaa siten kulttuurisen tunnistamisen merkitystä (Wilson 2009; Pennonen 2020).

Teoksen äänikerronnassa esiintyvät pohjoisen evakot joutuvat sopeutumaan Ruotsissa uuteen kulttuuriin ja kieleen. Kuvissa pakolaiset taas kohtaavat uuden kulttuurin suomalaisessa pohjoisessa maisemassa. Evakkous määrittyy elokuvassa ikään kuin rivienvälisesti - ilman, että sitä varsinaisesti määritellään - jossain määrin järjestäytyneen evakuoimisen, ylhäältä päin ohjatun väestön pakkosiirtelyn tulokseksi. Elokuvan ääniraidan evakkomuistot kertovat täyteen pakatuista junista ja viranomaisten ohjaamasta vastaanotosta Ruotsin puolella. Kuvien pakolaiset taas harhailevat omillaan pohjoissuomalaisessa maisemassa, kunnes kohtaavat viranomaiset elokuvan loppupuolella.

Elokuvateoksen fiktiivinen kuvakerronta rinnastuu siis historiallisiin lähteisiin perustuvaan ääniraitaan, joka koostuu autenttisista muistelufragmenteista, sekä lopputekstien yhteyteen liitettyihin vanhoihin valokuviin menneisyyden tapahtumista. Lopputeksteissä tuodaan myös esiin kerronnan pohjana olevat historialliset aineistot. Vuoden 1944 historiallisten tapahtumien selvittäminen sen sijaan jää katsojan oman kiinnostuksen varaan, ellei tämä niitä ennestään tunne.

Lopputeksteistä löytyviä lähteitä seuraamalla pääsee kuitenkin tapahtumien jäljille: syyskuussa 1944 katsottiin tarpeelliseksi tyhjentää Lappi siviiliväestöstä. Läänin 143000 asukkaasta evakkoon siirrettiin 103 885, heistä 56417 Ruotsiin, osa Pohjanmaalle tai muualle Suomen eteläisempiin osiin. Ruotsiin suurin osa siirtyi Tornion-Haaparannan kautta. Suurin osa pääsi palaamaan kotiseudulleen keväällä 1945, osa vielä myöhemmin. Saksalaiset polttivat suurimman osan Lapista, joten kotiinpaluu tapahtui tuhottuun ympäristöön. Osa evakoista jäi pysyvästi siirtopaikkakunnille. (Etto 1975, 4; Hautala-Hirvioja 2001, 266, 272; Tuominen \& Löfgren 2018.)

Lähtöön valmistautuminen aloittaa Rainion ja Robertsin teoksen kuvakerronnan dramaattisesti: arvoesineet kerätään ja haudataan, ja katsojan annetaan ymmärtää, että koti jätetään saman tien. Todellisuudessa ainakin rovaniemeläisten lähtö evakkoon kesti päiväkausia, kun lähtijät pakkailivat tavaroitaan, piilottivat astioita ja huonekaluja sekä teurastivat kotieläimiä. (Hautala-Hirvioja 2001, 266.) Ihmisten lisäksi evakkoon lähti myös runsas joukko lehmiä ja hevosia.

Myös Rainion ja Robertsin elokuvassa lehmän evakkomatkan esityksellä on keskeinen asema. Lehmän ilmestymistä kuvaan ennakoi romanttinen metsäluonnon kuvaus. Se toteutetaan sekä puunrunkojen lomasta siilautuvaa auringonvaloa tallentaen että varpu- tai mätäsperspektiivistä, sammalen tasolta. Tähän "suomalaisen luontosuhteen" arkkityyppiseen ympäristöön astelee kolmen nuoren miehen ja lehmän ryhmä. Yksi miehistä taluttaa lehmää, toinen kulkee lehmän vierellä sen kylkeä välillä taputellen ja kolmas kävelee peräpään tuntumassa, sitä ajoittain koivunvitsaksella leyhytellen. Kuulemme eläimen hengityksen, näemme sen varovaisen askelluksen ensin metsikössä, sitten pitkin koivukujaa taluttajiensa seurassa. 


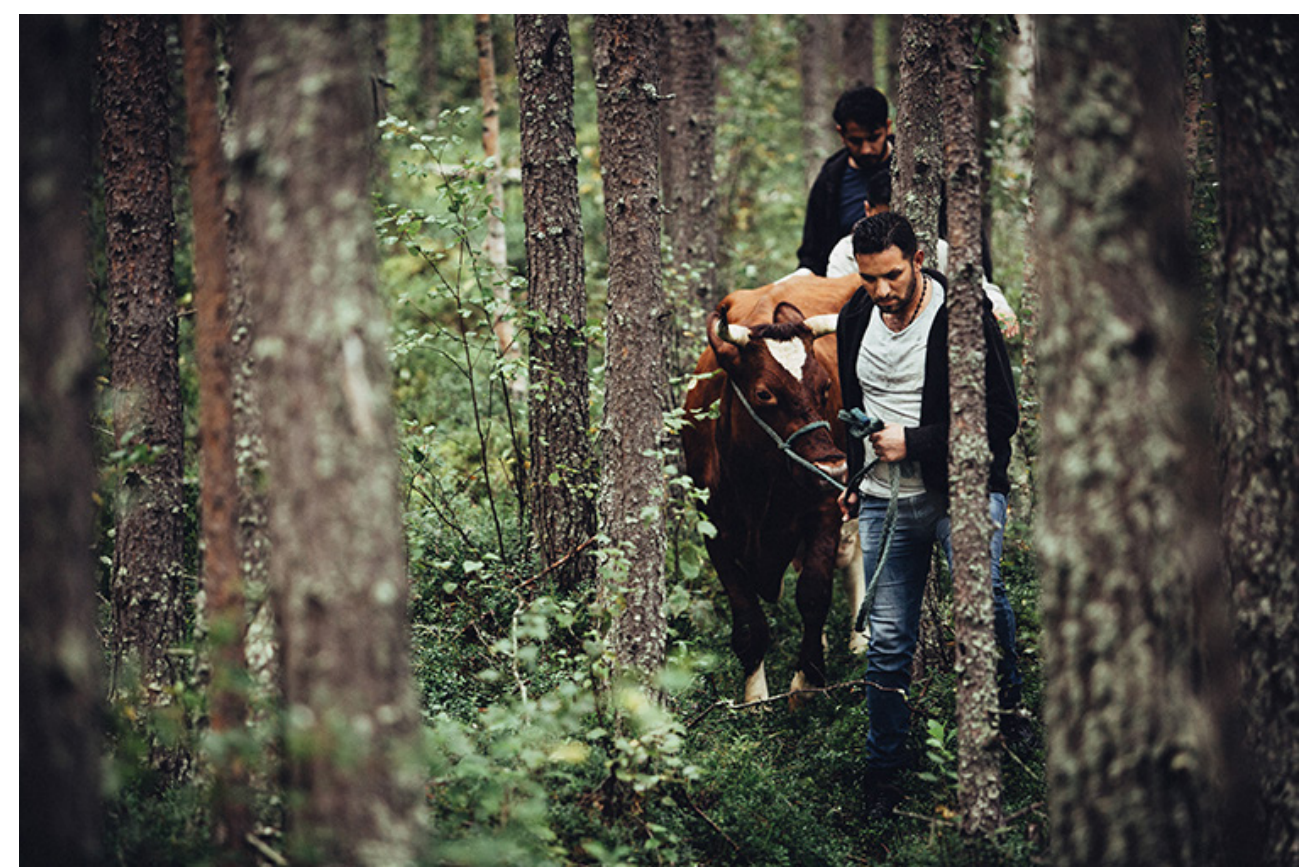

Ihmisten lisäksi evakkoon lähtivät sekä Rainion ja Robertsin elokuvassa että Lapin historiassa myös lehmät. Lähde: Minna Rainio ja Mark Roberts.

Lehmän kuljettaminen elokuvassa läpi syksyisen metsän perustuu historiallisiin tosiasioihin. "Lehmille tehtiin kylkeen maalilla tai tervalla omistajan nimikirjaimet, jotta ne löytyisivät suuresta laumasta. Useamman talon karja kerättiin kuljetusta varten yhteen. Kuljetuksesta, lypsämisestä ja ruokkimisesta vastasivat nuoret tytöt ja pojat sekä lievän haavoittumisen takia kotiutetut miehet." (Hautala-Hirvioja 2001, 267.) Elokuvan kertojaääni kuitenkin muistuttaa kuvakerrontaa raadollisemmasta todellisuudesta, kun kuvassa ilta hämärtyy ja pilvet peittävät taivaan: "Se kesti kolme viikkoa. Kävelimme 300 kilometriä. Kenkämme kuluivat rikki ja lehmien kynnet ${ }^{2}$ vuosivat verta", ääni kuvailee.

Katsomiskokemuksen kannalta olennaista on vuoden 1944 evakkojen sanallisten tarinoiden yhteneväisyys sen kanssa mitä nykypakolaisten pakomatkoista on kerrottu. Itse asiassa kerrontaa voi seurata melko pitkälle kuvitellen, että äänikerronta perustuisi kuvassa näkyvien henkilöiden muisteluun omasta pakomatkastaan. Lähtemisen kokemus yhdistää aikatasoja, ja ääniraidan historiallisuus saattaa unohtua välillä senkin jälkeen, kun katsoja jo tiedostaa, että ääni kertoo eri ajasta kuin kuva. Näin ääni ikään kuin muuntuu kuvassa olevien ääneksi ja kertomukseksi: kuvissa näkyvät henkilöt kertovat muiden elämästä, mutta katsoja voi silti pohtia, voisiko joiltakin osin kyseessä kuitenkin olla heidän tarinansa.

\section{Aikatasojen rinnastamisen haasteet}

Rainion ja Robertsin elokuva ei ole historiantutkimusta, mutta taideteoksena se asettuu osaksi historiakulttuuria. Henrik Meinander kirjoittaa, että historiantutkijan perushyveisiin kuuluu "kyky liikkua oman kulttuurinsa ja mukavuusalueensa ulkopuolella ja kyseenalaistaa omien tulkintojensa uskottavuus. Kyse on loppujen lopuksi niinkin yksinkertaisesta tai monimutkaisesta asiasta kuin
2 Suomenkielisessä tekstityksessä englannin "hoofs" on jostain syystä kääntynyt kynsiksi, vaikka kyseessä ovat sorkat. 
toisen ihmisen ymmärtäminen." (Meinander 2016, 66.) Teoksen perusajatus voisikin olla sama kuin historiantutkimuksen: toisen ihmisen kokemukseen ja asemaan asettuminen. Taiteilijat tarjoavat oman tulkintansa historiasta ja yhtä lailla nykyisyydestä, ja kutsuvat katsojan mukaan tulkintaan. Kahden aikatason rinnastaminen ei kuitenkaan ole ongelmatonta.

Elokuvan ajallisessa kaksoisvalotuksessa nykyturvapaikanhakijat asetetaan esittämään monen vuosikymmenen takaisia tapahtumia. Yhtäältä voidaan ajatella, että he tulkitsevat historiallista evakkomatkaa. Toisaalta etelästä tulleina turvapaikanhakijoina he ovat läsnä suomalaisessa maisemassa, omassa nykyhetken todellisuudessaan, ja kantavat mukanaan omaa historiaansa, johon niin ikään kuuluu lähteminen kotoa. Heidän omat muistonsa ja kokemuksensa jäävät kuitenkin elokuvateoksessa näkymättömiin; heidän tarinansa on toki läsnä implisiittisesti, eleissä, ilmeissä, ruumiillisessa läsnäolossa, mutta sanallista kerrontaa hallitsevat historiallisten pakolaisten kokemukset. Tästä näkökulmasta tulkittuna eteläiset turvapaikanhakijat näyttelevät suomalaista evakkohistoriaa, samaa kertomusta, joka on kerrottu monesti ennenkin, ilman, että he pääsisivät tuomaan siihen oman näkökulmansa. Katsojina emme kuuntele heidän ääntään, vaan pohjoisten evakkojen ääntä - näin Rainion ja Robertsin ratkaisu mutkistaa entisestään asetelmaa, jossa länsimainen taiteilija "antaa äänen" kolmatta maailmaa tai etelää edustavalle (Horsti 2019).

Toisaalta juuri se, että kuvakerronnassa esiintyvät turvapaikanhakijat jäävät ikään kuin vaille omaa tarinaa, voi herättää katsojassa kiinnostusta, uteliaisuuttakin. Myös aiemmissa teoksissaan Rainio ja Roberts ovat monesti herätelleet katsojaa juuri niukkuuden keinoin: esimerkiksi Kahdeksan huonetta -teoksessa (2008) nimenomaan se, ettei tapahtumia esitetä, herättää mielikuvituksen ja katsoja voi sijoittaa oman tulkintansa tyhjiin huoneisiin. Yhtä lailla myös They Came in Crowded Boats and Trains -teoksen eteläiset pakolaiset saattavat kutsua kysymään, mikä on heidän tarinansa. Suomalaiseen evakkotarinaan yhdistäminen irrottaa etelän pakolaiset samaan aikaan heidän omasta oletetusta ympäristöstään, ja toisaalta herättää kysymyksen siitä, mistä tämä oletettu mielikuva pakolaisuudesta muodostuu. Onko pakolaisuudessa yhteisiä, kaikille ajoille ja paikoille tyypillisiä piirteitä? Vai onko jokaisen pakolaisen tarina erilainen? Millä edellytyksillä voidaan verrata pakolaisuuksia, jotka juontavat hyvin erilaisiin poliittisiin tapahtumakulkuihin, konflikteihin, ristiriitaisiin tulkintoihin ja tilanteisiin? (Ks. Ahonen 2018, 5, 8.)

They Came in Crowded Boats and Trains asettuu luontevasti keskusteluun muutamien muiden historiallisia rinnastuksia tekevien taideteosten kanssa. Tutkija Karina Horsti on analysoinut taiteilija Timo Wrightin audioinstallaatiota The Long Journey Home (2012/2017), jossa nykypakolaisten, Karjalan evakkojen sekä Ruotsiin lähetettyjen sotalasten tarinat lomittuvat. Näyttelijä Vesa Vierikko tulkitsee teoksessa kaikki tarinat, joissa ei mainita nimiä tai paikkoja. Horstin tulkinnan mukaan teos olettaa kuulijan tuntevan suomalaisevakkojen tarinat, joiden kautta oletetaan syntyvän myös valmius ymmärtää nykypakolaisuutta. Näin evakkous ja pakolaisuus kiinnittyvät kansalliseen, suomalaiseen kokemukseen - tai pikemminkin välittyneeseen kokemukseen, mielikuvaan, joka on syntynyt esimerkiksi eri medioiden välityksellä. Kun ristiriidat ja epämukavuudet siivotaan pois, on vaarana, että teos luo kauniin kuvan vain yhdenlaisesta evakosta, tarinan, joka etäännyttää kuulijan. Kiteytyneestä tarinasta yksilöiden erot ja myös historialliset taustat ja syyt pakolaisuuteen - sota, uskonto, seksuaalisuus - on häivytetty; tuloksena on abstrakti pakolaishahmo. Horstin mukaan Wrightin installaatio tarjoaa kuitenkin mahdollisuuden siihen, että myös nykyiset pakolaiset luetaan mukaan 
kansalliseen "meisyyteen", ja erilaiset muistot lähtemisestä keskustelevat keskenään ja täydentävät toisiaan. (Horsti 2019, 136.) Rainion ja Robertsin teoksen suhteen voi kysyä, miten teosta ja sen potentiaalista vastaanottoa olisi muuttanut se, jos äänikerronnassa oltaisiinkin yhdistelty pohjoisiin evakkotarinoihin eteläisten pakolaisten kertomuksia?

Toinen esimerkki historiallisten pakolaiskokemusten rinnastamisesta nykyisiin on Magnus Gerttenin elokuva Hoppets hamn, joka sai ensi-iltansa Malmössä syyskuussa 2011. Neljä vuotta myöhemmin teos sai jatko-osan nimeltä Varje ansikte har ett namn. Yhtäältä elokuvat kertovat tarinaa Malmön satamaan vuonna 1945 Punaisen Ristin avulla saapuneista henkilöistä. Toisella tasolla liikkuu kertomus yleisemmästä, universaalimmasta ja ajattomasta paikattomuuden ja omasta paikasta pakotettuna siirtymisen kokemuksesta. Kuvakerronnassa siirrytään Malmöstä Sisiliaan, jonne pakolaisia kuljettavat laivat saapuvat; kuvat ovat teosta tulkinneiden tutkijoiden mukaan hämmentävän samankaltaisia. Kerronnassa lähdetään yksityisistä aikalaistodistajan muistoista ja päädytään laajempaan, pakolaisuutta koskevaan kulttuuriseen muistamiseen. Rinnastamalla tunnistettavia, symbolisesti pakolaisuuteen liittyviä kuvia satamista ja laivoista katsojalle tarjotaan mahdollisuus tunnistaa mennyt nykyisessä. (Wagner \& Seuferling 2020, 97-98.) Samaan tapaan Rainio ja Roberts tarjoavat tunnistamisen paikkoja eri aikatasoja lomittavassa teoksessaan. Sekä Gerttenin elokuvien että They Came in Crowded Boats and Trains -teoksen äärellä voidaan toki pohtia, millaista kokemusta rinnastus tuottaa katsojalle, jolla ei itsellään ole kokemusta pakotetusta lähtemisestä.

Rainion ja Robertsin teoksesta löytyy esimerkki hiukan ilkikurisestakin aikatasojen ja kokemusten rinnastamisesta. Kertojaääni sanoo: "Ollakseni rehellinen, ruoka ei ole kovin hyvää." Vaikka pohjoisesta Suomesta lähteneet evakot eivät päätyneet kovin kauas, ruotsalaisen kulttuurin tavat ja koko yhteisö kuitenkin olivat heille vieraita. Mainintoja ruuasta on muisteluissa useita - ruisleipään tottuneet suomalaiset oudoksuivat vaaleaa leipää, ja muutenkin ruotsalaista ruokaa pidettiin liian makeana (Hautala-Hirvioja 2001, 276). Suhtautumisessa ruokaan löytyy yhtymäkohta myös vuonna 2015 Suomeen saapuneisiin. Heti lokakuussa kohistiin mediassa siitä, kuinka Oulussa ryhmä maahan tulleita osoitti mieltään heille tarjottua (koulu)ruokaa vastaan (Punkari 2015; Annila 2015). Käyttämällä vuonna 1944 sanallistettua tarinaa ja liittämällä sen visuaaliseen kerrontaan, jossa etelästä tulleet nykypakolaiset asettuvat vastaanottokeskukseen Rainion ja Robertsin teos rinnastaa pohjoisesta lähteneiden ja pohjoiseen tulleiden pakolaisten kokemukset hyvin konkreettisesti. Ruoka on teema, jonka yhteydessä pakolaisen hahmoon liitetty kiitollisuuden vaade tulee esiin sekä yhteydessä Lapin sodan muistoihin että nykypakolaisiin. Elokuvassa kertoja kuvaa tulijoiden kiitollisuuden tunnetta juuri ennen ruuan kommentointia: "Me olemme vain kiitollisia. Niin monet ihmiset haluavat auttaa meitä ja tutustua meihin. He huolehtivat ja välittävät meistä." Ehkä hivenen sarkastisena visuaalisena rinnastuksena tämän repliikin aikana kuvassa näytetään, kuinka sotilashenkilö johdattelee turvapaikanhakijaa vastaanottokeskuksen yläkertaan. Meille näytetään siis viran puolesta tapahtuvaa "huolehtimista", kontrollia ja valvontaa, ei niinkään spontaania auttamista ja tutustumista.

"Kantaväestön" tai valtaväestön toistuvasti pakolaisiin kohdistamaa kiitollisuuden vaatimusta (ks. esim. Annila 2015) voi tulkita myös seuraillen feministifilosofi Sara Ahmedin (2000) hahmottelemaa "muukalaisen figuurin" muodostumista. Epäkiitollisuus on ominaisuus, jonka "meitä" ja "heitä" toisistaan selkeästi erottavat sosiaalisen median ja kommenttipalstojen keskustelijat 
ikään kuin liimaavat ei-toivotun vieraan, muukalaisen hahmoon. Se tarttuu median kaiuttamana ja jää tahmeasti kiinni stereotyyppiseen käsitykseen toisista, jotka merkityksellistetään perustavanlaatuisesti erilaisiksi kuin "meidät". Rainion (2016) mukaan teoksen yhtenä tavoitteena on sekä tunnistaa itsemme muukalaisissa että muukalainen itsessämme. Kerrostuneella kerronnallaan elokuva saattaa myös herättää jälkikoloniaaleja kysymyksiä vieraanvaraisuudesta (ks. esim. Nikunen 2018), riippuvaisuudesta, vastuusta ja huolenpidosta.

\section{Rajanylittäjien sukupuoli ja rajojen vartiointi}

Osa sekä 1940-luvun ruotsalaisesta että nykysuomalaisesta pakolaisvastaisuudesta (jälkimmäisestä ks. esim. Saresma 2018; Pöyhtäri 2018) liittyi niin Lapin sotaa paenneiden pohjoissuomalaisten kuin vuoden 2015 Suomeen pyrkineiden pakolaisten tapauksissa sukupuoleen ja oletettuun rajoja rikkovaan heteroseksuaalisuuteen. Maija Urponen on muistuttanut siitä, kuinka feministinen nationalismitutkimus on kiinnittänyt huomiota naisten ruumiillisuuteen kansallisten rajojen ylläpitämisen kohteena kautta historian: "Kansallisista rajoista taisteltaessa korostuu ajatus naisista kansallisena omaisuutena", Urponen kirjoittaa $(2010,61)$. Tutkimus on tuonut esiin myös nykyisen, rajojen vartiointia ja sulkemista vaativan puheen sukupuolittumisen (Saresma 2018; Pöyhtäri 2018). Vuodesta 2015 lähtien julkisessa keskustelussa nousi usein esiin huoli nuorten miesten vahvasta edustuksesta Suomeen saapuneiden turvapaikanhakijoiden joukossa (Helminen 2016; Saresma 2018; Pöyhtäri 2018). Tähän ilmiöön on kytketty toistuvasti uhkapuhetta liittyen suomalaisten naisten ja tyttöjen turvallisuuteen. Maahanmuutto- ja pakolaisvihamielisessä sosiaalisessa mediassa on toisteltu käsityksiä miespakolaisista, joiden pelotellaan viettelevän ja raiskaavan "meidän naisemme". Samoissa keskusteluissa toistuu myös fiktiivinen "suvakkihuoran" hahmo, jolla viitataan ulkomaisiin miehiin naiivisti suhtautuviin - ja seksuaalisesti suuntautuviin - suomalaisiin naisiin. (Sundén \& Paasonen 2018.) Ajoittain myös muu media on päätynyt toistamaan ja uusintamaan sosiaalisessa mediassa kuohunutta vihapuhetta ja maahanmuuttokielteisyyttä (Pöyhtäri 2018, 92).

Tässä kontekstissa on kiinnostavaa tarkastella miten merkityksellistyy se, että myös Rainion ja Robertsin elokuvassa suurin osa esiintyjistä on nuoria miehiä, alun ja lopun kohtauksissa keskeisessä asemassa esiintyvää pikkutyttöä ja aivan muutamaa aikuista naista lukuun ottamatta. Kyseessä oli käytännön sanelema ratkaisu: miehiä oli helpompi löytää kuvauksiin (Rainio 2016). Näin tavallaan sattuman tuottama roolitus heijasti myös vuonna 2015 Suomeen tulleiden turvapaikanhakijoiden sukupuolijakaumaa: 81 prosenttia heistä oli miehiä (Helminen 2016). Tapa, jolla Rainio ja Roberts kuvaavat henkilöhahmojaan, ei tuo mitenkään esiin näiden seksuaalisuutta eikä korosta myöskään maskuliinista sankaruutta. Itse asiassa kuvien esittämää mieheyttä voi lukea yhtäältä feminiinisenä (lehmää taluttavat miehet eläintä hoivaavina), luonnonvoimien armoilla avuttomana olevana tai viranomaisten edessä alistuvana.

Rainio ja Roberts käyttävät They Came in Crowded Boats and Trains -teoksessa kerronnallisena keinonaan toistuvasti kuvan ja sanan ristiriitaa. Näin myös sukupuolten esittämisessä vastaanottokeskuskohtauksessa. Siinä missä visuaalisesti kuvissa esiintyvät nykypakolaiset ovat pääosin nuoria miehiä, olivat Lapin pakolaiset vuonna 1944 puolestaan etenkin naisia, lapsia ja niitä miehiä, jotka eivät olleet sotimassa (Hautala-Hirvioja 2001). Historiantutkimus 
kertoo kuitenkin myös suomalaisten evakkomiesten käytökseen Ruotsissa liittyneistä ongelmista: "Tekemisen puute vaivasi erityisesti työkuntoisia miehiä, ja nämä keksivät omat harrastuksensa. Kiljun tekeminen ja juopottelu johtivat konflikteihin, ja jopa viranomaiset joutuivat toisinaan puuttumaan tilanteisiin" (Hautala-Hirvioja 2001, 282).

Elokuvassakin kertoja toteaa, että ruotsalaisista osa piti Suomesta tulijoita moraalittomina, naistenmiehinä ja juoppoina, jopa rikollisina. Toteamus rinnastetaan kuvaan, jossa nuori musta mies heittää noppaa ja taustalla näkyy nuori valkoinen nainen punaisen ristin asussa siivoamassa. Miehen ja naisen välille ei rakenneta visuaalisesti minkäänlaista eroottista jännitettä. Tältä osin nykymaahanmuuttaja ei "roolituksessaan" toista äänikerronnan kuvausta, vaan kuvittaa pikemminkin vain edellä mainittua tekemisen puutetta ja harmittoman harrastuksen keksimistä. Historiallinen teksti taas asettaa suomalaiskatsojat peilin eteen: "meistäkin" on esitetty maahantulijoina sukupuolittavia, seksualisoivia ja moraalisesti tuomitsevia kommentteja.

Sen sijaan, että Rainion ja Robertsin teos vahvistaisi julkisessa keskustelussa kierrätettyjä stereotyyppisiä kuvia miesmaahanmuuttajista, se osallistuu niin ikään mediassa tuotettuihin ja toistettuihin solidaarisuuden kokemusta ruokkiviin kuvastoihin. Myös taiteilijoiden tekemät tyylilliset valinnat - rauhallinen tempo, väkivallan näyttämättömyys ja suorastaan runollinen maisemakuvaus - saattavat edesauttaa sitä, että katsojat eivät sen nähdessään koe "myötätuntouupumusta" (Kivikuru, Maasilta \& Nikunen 2018, 12; Haavisto \& Maasilta 2018, 128-131), vaan erilaisia samastumisen ja jakamisen tunteita.

\section{Rajanylitys, tulevaisuus ja toivo}

Pakolaisuuteen liittyy aina epävarmuus. Epävarmuus siitä, pääseekö turvaan, mitä tulee tapahtumaan, tuleeko uudessa paikassa hyväksytyksi. Tuleeko uudesta maasta ja paikasta koti - ja jos tulee, niin millainen (Huttunen 2002)? Pääseekö entiseen kotiin koskaan enää palaamaan takaisin? Tuntemattomaan paikkaan siirtymiseen ja rajalla olemiseen liittyy toisten armoille joutuminen ja se, ettei omaa tulevaisuuttaan - tai edes nykyhetkeään - voi hallita.

Suomesta Ruotsiin siirtyneet evakot olivat konkreettisesti vastarannalla ja näkivät joen yli, kun Suomi paloi, eikä mitään ollut tehtävissä. Tämä kerrotaan myös Rainion ja Robertsin elokuvassa, vaikka palavia taloja ei visuaalisessa esityksessä näytetäkään.

Kun kertoja kertaa suomalaisevakoiden muistoja kotikaupungin räjäyttämisestä ja polttamisesta, ääni kontrastoituu rauhallisiin kuviin vedestä, veden pintaa verkkaan halkovista airoista ja ohi lipuvista veneistä. Kuva ei toista äänikerronnan kaoottisuutta ja väkivaltaisuutta. Sitä vastoin kuvakerronnallinen "rajanylitys" päättyy rantaan pääsemiseen, siihen kun veneet vedetään rantatörmälle ja pelastusliivit heitetään maihin. Erillinen kuva esittää myös veteen kellumaan jäänyttä yksittäistä liiviä. Tämä elokuvan hetki rinnastaa sen, ehkä jopa sentimentaalisesti, muutamiin muihin Välimeren pakolaisuutta käsitelleisiin taideteoksiin: esimerkiksi kiinalaistaiteilija Ai Weiwein poseeraukseen Lesboksen saaren rannalla hukkuneen pikkupojan Alan Kurdin asentoa valokuvassa toistaen (2016), suomalaisen kuvanveistäjän Pekka Jylhän Alan Kurdia esittävään nukkemaiseen veistokseen (2016) ja jo edellä mainitun Timo Wrightin Kharon-installaatioon (2016), joka muodostui Lesboksen saarelta taiteilijalle toimitetuista pelastusliiveistä (Korte 2016; Viljanen 2016). Lyhyessä ajassa juuri pelastusliiveistä oli tullut Välimeren pakolaisten 
hukkumiskuolemien symboli, jota käyttämällä taiteilijoiden ei tarvinnut turvautua Weiwein ja Jylhän tavoin kuoleman näköisesityksiin. Itsekseen kelluva pelastusliivi kertoo rajanylityksestä, joka ei onnistunut.

Rainio ja Roberts ovat aiemmissakin teoksissaan käsitelleet rajaa monista näkökulmista: Suomen ja Neuvostoliiton rajaa teoksessa Rajamailla (ks. Rainio 2005) ja pakolaisten kokemia raja-asemia, poliisiasemia ja vastaanottokeskuksia teoksessa Kohtaamiskulmia (Rainio 2015). Tilat, joihin pakolaiset joutuvat, kuten raja-asemat, ovat välitiloja ja läpikulkutiloja, mutta samalla myös emotionaalisen ja taloudellisen vallankäytön sekä määrittelyn, kuulumisen ja ulossulkemisen tiloja (Rainio 2015, 73). They Came in Crowded Boats and Trains kuvaa vieraaseen maahan saapumista muutaman tiiviin kohtauksen kautta: rajamuodollisuudet, paikallisten kohtaaminen vastaanottokeskuksessa ja kylän raitilla. Se, mitä tapahtuu elokuvassa esitettyjen tapahtumien jälkeen, jää katsojan pohdittavaksi.

Historialähteet kertovat, kuinka vuoden 1944 syksyllä Lapin evakkojen mielessä kyti epävarmuus omasta ja läheisten sekä kotiseudun tulevaisuudesta. Pohjoisen Suomen tulevaisuus oli hämärän peitossa, ja lappilaiset olivat varmoja, että Neuvostoliitto miehittäisi alueen. Evakkoon lähdettäessä ei siis ollut tietoa, päästäisiinkö kotiseudulle koskaan palaamaan. Tietoa saatiin niukasti, eikä yhteyttä omaisiin saatu yhtä nopeasti kuin nykyään sosiaalisen median aikakaudella. Pelko tulevaisuutta ja vierasta maata ja kulttuuria kohtaan eli monen mielessä. (Hautala-Hirvioja 2001, 271.)

Jälkiviisaina tiedämme nyt, miten sodan jälkeen kävi. Paluu oli lopulta mahdollinen suurimmalle osalle pakolaisista - Petsamon evakot eivät tosin koskaan päässeet palaamaan. Jälleenrakennuksen eetos, paluu savupiippukyliin ja elämän rakentaminen uudestaan tyhjästä eivät häivyttäneet evakkoajan kokemuksia, mutta arkea oli silti elettävä. Lapin sodan evakkojen kokemukset eivät välttämättä ole yhteneväisiä, mutta historiallisena kertomuksena ne ovat tiivistyneet tietynlaisiksi, ja tähän kuvaan myös Rainion ja Robertsin elokuvateos viittaa. Sota muutti kaikkien elämää, ja pohjoisiin yhteisöihin se jätti jäljen, joka ei poistunut: esimerkiksi saamelaisyhteisöjen elämä muuttui Pohjanmaalla vietettyjen evakkovuosien jälkeen radikaalisti (ks. Lehtola 2018). Mentaalinen jälleenrakennus käynnistyi vähitellen, mutta materiaalisten muistojen kuten esineiden ja valokuvien puuttuminen vaikutti yhteisön muistiin ja yksilöiden elämän jatkuvuuden tunteeseen. Lisäksi monet sotaan liittyvät aiheet kuten sotalapset ja saksalaisten sotilaiden kanssa solmitut suhteet olivat pitkään vaiettuja asioita. (Tuominen \& Löfgren 2018; Lehtola 2018; Lähteenmäki 1999.) Myös ruotsalaisiin, "rauhalliseen ja hyvinvoivaan kansankotiin", pakolaisten saapuminen sodan haavoittavista olosuhteista vaikutti syvällisesti (Rautio 2004, 9).

Lähi-idästä ja Pohjois-Afrikasta tulleiden pakolaisten suhteen emme vielä voi tietää, millainen tulevaisuus on: se, miten kaikki "päättyy" tai jatkuu, millaiseksi kertomus lopulta rakentuu, kenen ääni tulee kuulluksi ja kenen kokemuksista vaietaan, ei vielä ole tiedossa. Pakolaisten liikkumisella on vaikutuksia paitsi siihen yhteiskuntaan, josta he ovat lähteneet, myös heihin itseensä ja sen paikan asukkaisiin, johon he saapuvat. They Came in Crowded Boats and Trains -elokuvaa katsoessa ja kuunnellessa voi pyrkiä välillisesti hahmottamaan niitä kokemuksia, joita vuoden 1944 evakko koki - kaiken sen tiedon varassa, joka meillä nyt on menneisyydestä. Samalla voi kuitenkin pyrkiä ymmärtämään myös sitä tilannetta ja mentaalista maailmaa, jossa vastikään Suomeen saapunut eteläinen pakolainen käy kokemuksiaan läpi. Tulkinnat menneisyydestä muodostuvat paitsi omien ja läheisten, esimerkiksi 


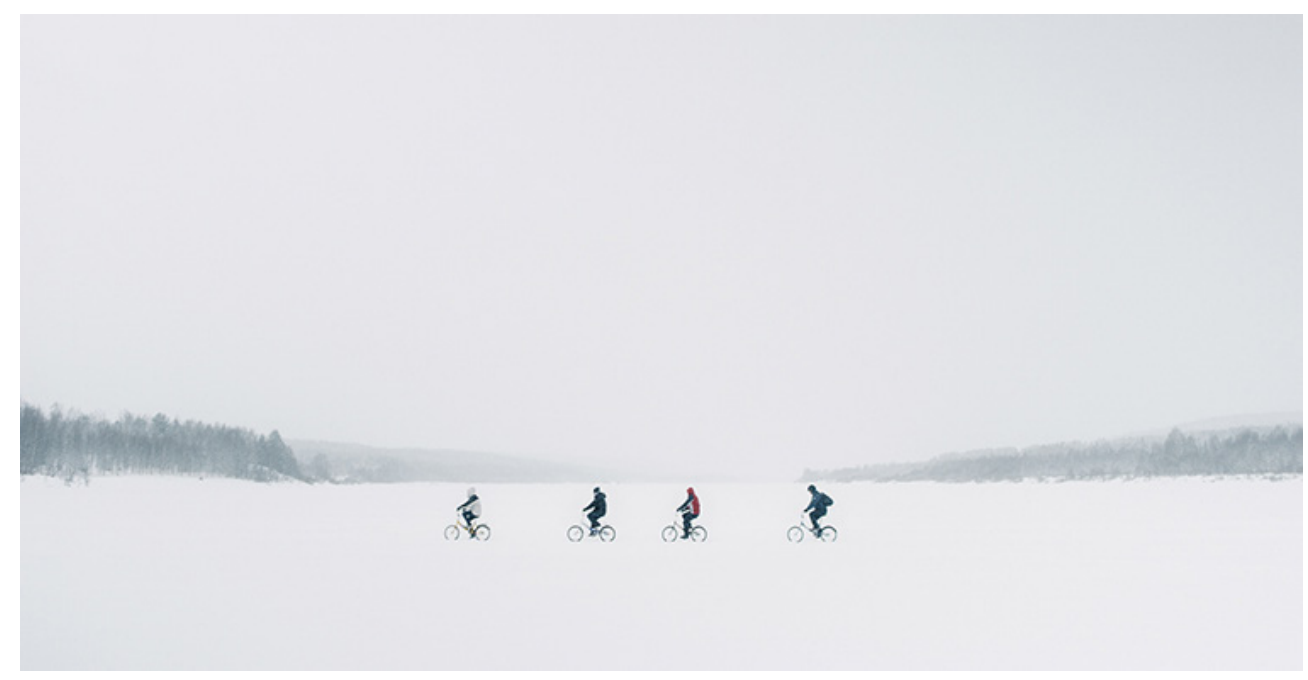

Pyöräilevät pakolaiset etenevät verkkaisesti lumisessa maisemassa. Lähde: Minna Rainio ja Mark Roberts.

sukulaisten, kokemusten kautta, myös historiallisen tiedon ja historiakulttuurin avulla.

Elokuvan alussa ja lopussa esiintyvän pikkutytön figuuri toimii kerronnassa tulevaisuuden ja toivon merkitsijänä: vaikka tyttö seuraa pakoon lähdön valmistelujen ankeutta - esimerkiksi arvoesineiden hylkäämistä ja hautaamista mutaiseen maahan - aivan vierestä, hän elokuvan loppuminuuteilla näyttäytyy iloisena ja hetkessä elävänä hahmona. Vastaanottokeskuksessa tyttö pyörittää hulavannetta letit liehuen ja hymyillen. Kun aikuinen kertojaääni kommentoi oleilua keskuksessa toteamalla, että siellä sodasta kärsineet saavat levätä ja olla rauhassa, kuullaan myös tarinan ainoat diegeettisesti esitetyt sanat. Tyttö puhuttelee ennen nukahtamistaan isäänsä ja kysyy "Jäädäänkö me tänne?" Emme kuule isän vastausta, vaan kuva siirtyy leikkauksen kautta lumiseen maisemaan, jossa nuorten miesten pyöräilijäjono jälleen kerran ylittää kuva-alan oikealta vasemmalle, kuin arabian kielellä kirjoitettaessa. Kuva-alaan ilmestyy kirjoitettuna sitaatti 15. syyskuuta 1944 päivätystä kenraali Rosenbladin kehotuksesta Ruotsin evakuointiviranomaisille, sotilaille ja vapaaehtoisille: "He tulevat henkisesti väsyneinä eikä heidän tulevaisuutensa näytä valoisalta. Jokainen meistä pitäköön tämän mielessään nyt kun ryhdymme heitä auttamaan." Näin elokuvan tekijät siirtävät velvoitteen vieraanvaraisuudesta myös nykyhetken suomalaisille katsojille - tai kenelle tahansa nykykatsojalle, joka kohtaa pakolaiskysymyksen tai turvapaikanhakijoiden tilanteen omassa arjessaan.

\section{Teoksen vastaanotto: alistushistoriat ja samastuminen}

Historiakulttuuri auttaa meitä ymmärtämään omaa olemassaoloamme tapahtumien jatkumossa. On tärkeää kiinnittää huomiota siihen, kenellä on oikeus määritellä mitä menneestä muistetaan, mikä on muistamisen arvoista, ja kenen kokemukset jäävät piiloon. (Grönholm \& Sivula 2010, 11-12; Kalela 2010, 40.) Oman ja muiden historioiden yhtymäkohtia voidaan käyttää herättämään empatiaa ja ymmärrystä. Esimerkiksi ruotsalaisia ja saksalaisia pakolaisdo- 
kumenttielokuvia vertailleet Hans-Ulrich Wagner ja Philipp Seuferling (2019, 94) kirjoittavat, että erilaisten pakolaisuuden ja siirtolaisuuden kokemusten yhtymäkohtien "fasilitoiminen" mahdollistaa yleisöille eräänlaisen aikamatkan, joka auttaa kuvittelemaan uudelleen omia ja muiden muistoja, ja yhdistämään muistoja nykypäivään. Olennaista on kuitenkin myös, kenen äänellä kerrotaan se, mitä muistetaan. Karina Horsti on varottanut yhtenäisen ja yhdenmukaisen "pakolaisen äänen" kuvitelmasta ja siitä valta-asetelmasta, jossa pakolaisuutta käsittelevät taiteen ja elokuvantekijät "antavat äänen" kohteilleen $(2019,126)$. Kuten olemme edellä todenneet, Rainion ja Robertsin elokuvassa esiintyvät turvapaikanhakijat eivät kerro omista kokemuksistaan, vaan esittävät taiteilijoiden tulkitsemaa pohjoisten pakolaisten historiaa. Rainion (2020) mukaan esiintyjät eivät myöskään elokuvan tekoprosessin aikana kovin paljon artikuloineet kokemuksiaan, mutta he olivat kiitollisia saadessaan olla mukana elokuvan teossa. Esittäessään vuonna 1944 eläneiden ihmisten evakkomatkaa he kuitenkin toivat jonkin verran esiin omia kokemuksiaan ja puhuivat niistä löytäen yhtäläisyyksiä historiallisiin kertomuksiin.

Teoksen julkaisun jälkeen se elää omaa elämäänsä, eivätkä tekijät välttämättä saa kovin paljon palautetta tai tietoa teoksen vastaanotosta. They Came in Crowded Boats and Trains ei ole esillä esimerkiksi Youtubessa, vaan sen katsomistilanteet on yleensä rajattu esimerkiksi galleriatilaan tai elokuvanäytöksiin festivaaleilla. Esityspaikan valinta ja rajoittaminen voi olla myös eettinen valinta: esimerkiksi aiemman Kohtaamiskulmia-teoksensa kohdalla taiteilijat ovat olleet tarkkoja, jotta haastateltujen pakolaisten henkilökohtaiset, kipeätkin kokemukset saisivat tilaa, ja jotta myös esitystilanne kunnioittaisi näitä kokemuksia. (Rainio 2015, 76.) Voidaan tietysti pohtia, millaisen vastaanoton teos saisi, jos sen voisi katsoa kuka tahansa - ja toisaalta, millaista kulttuurista ja historiallista tietämystä katsojalta oletetaan. Pitääkö hänellä olla ainakin jonkinlainen käsitys Lapin sodasta, sen tapahtumista ja seurauksista? Herättääkö teos kiinnostuksen pohjoista historiaa kohtaan, saako se etsimään tietoa vuoden 1944 tapahtumista Lapissa? Vai torjuuko katsoja rinnastuksen historiallisten tapahtumien ja nykyajan välillä? Millaisia tunteita elokuvan näkeminen herättää evakkoajan Lapin sodan aikana kokeneissa tai heidän läheisissään, tai elokuvan esiintyjissä?

Minna Rainio kertoo, että Turussa, Ars Nova -museossa pidetyn ensi-illan jälkeen monet katsojat olivat tulleet keskustelemaan, ja joitain teos oli koskettanut kyyneliin asti. Yksi Karjalan evakko oli tullut kiittämään, ja myös Turku Biennaalin palautteissa on seuraava kommentti: "Pakolaiselokuva!! <3 terv. pakolaisten 1939 (Karjala) ja 1944 (Rovaniemi) jälkeläinen ja pakolaisten 2015 auttaja Lapista". Biennaalissa kerätyssä palautteessa korostuu, miten teos saa ajattelemaan, muistuttaa menneistä tapahtumista ja toisaalta pakolaiskysymyksen ajankohtaisuudesta. Yhdessä palautteessa mainitaan, että teos "palautti kutkuttavasti uskon taiteen mahdollisuuksiin vaikuttaa". Muutama myös kommentoi, että monen olisi hyvä nähdä elokuva - yksi katsoja jopa kirjoittaa, että "Sen katsominen tulisi olla jokaisen ihmisen velvollisuus." Yksi palaute yhdistää teoksen tapahtumat Karjalaan, Lappia paikkana ei mainita kuin yhdessä. (Rainio 2020.)

Rainion mukaan taideteokset eivät tarjoa valmiita ajatuksia tai näkökantoja, vaan katsoja itse ajattelee ja aistii teokset. Katsoja myös täyttää kuvan ja kielen väliin jäävän tilan omien kokemustensa ja muistojensa avulla. (Rainio 2015, 114, 162.) They Came in Crowded Boats and Trains -teos sijoittuu Lappiin, mutta katsojat eivät siis välttämättä tunnista "Lapin merkkejä" maisemakuvauksesta. Näin kokemukset sodasta ja pakolaisuudesta voivat laajeta yleisemmäksi 
ymmärrykseksi, jaetuksi käsitykseksi siitä, millaista on lähteä ja saapua. Aikatasojen merkitsemisessä käytetty nykyvaatetuksen arkisuuskin voi edesauttaa tulkintaa maahanmuuttajista "ei minään erityisenä kuljeskelevana ihmistyyppinä, vaan enemmän tai vähemmän tavallisina eri yhteisöjen jäseninä, joiden elämässä tulee syy tai pakottava tarve muuttaa paikasta toiseen", kuten Laura Huttunen $(2002,331)$ on kuvannut muukalaisen arkkityypin murenemista. On mahdollista, että aikatasojen rinnastuksen, kerrostamisen ja toisiinsa lomittamisen herättämän myötätunnon avulla teos osallistuu myös katsojien tietoisuuden dekolonisaatioon, kun erilaiset alistushistoriat ja vallankäytön seuraukset kohtaavat audiovisuaalisessa kerronnassa toisensa.

\section{Lopuksi}

Kysyimme artikkelimme alussa, mitä kahden erilaisen ja eriaikaisen pakomatkan rinnastus elokuvassa saattaa tuottaa suhteessa pakolaisuuteen, pohjoisuuteen ja sukupuoleen liittyviin kuvastoihin. Olemme tarkastelleet Minna Rainion ja Mark Robertsin elokuvaa They Came in Crowded Boats and Trains historiakulttuurin käsitteen valossa. Pakolaisen figuuri hahmottuu teoksessa moniulotteisena: siihen vaikuttavat niin vanhat kuin uudet sukupuolittuneet stereotypiat, mutta myös niiden rikkominen. Rinnastamalla ruotsalaisten suomalaisevakkoja kohtaan tuntemat ennakkoluulot suomalaisten etelästä tulleita nykypakolaisia kohtaan tuntemiin Rainio ja Roberts patistavat katsojiaan kyseenalaistamaan etnistävien tai rodullistavien yksioikoisten käsitysten perustaa. Elokuva sekä toistaa tunnistettavia pakolaiskuvia (vesistön ylittäminen, pelastusliivit Välimeren pakolaisuuden symbolina) että liikahduttaa niitä suhteessa paikkaan ja maantieteeseen: nuoret miehet, joita suomalainen media on esittänyt lähinnä urbaaneissa olosuhteissa tai vastaanottokeskuksissa, näytetään teoksessa osana pohjoista maisemaa ja paikan ehdoilla selviytyvinä.

Teos kuvaa myös pohjoista osin stereotyyppisesti esteettisenä kansallismaisemana, mutta sijoittamalla maisemaan nykyturvapaikanhakijoiksi tunnistettavat esiintyjät se myös mahdollistaa uudenlaisen tulkinnan siitä, ketkä pohjoiseen voivat ja saavat kuulua - keiden tulevaisuus voi olla pohjoisessa? Niin ikään teos saattaa laajentaa yleistä käsitystä suomalaisesta evakosta: tämä kuva on jo itsessään ollut hyvin kapea - siihen eivät ole kuuluneet PohjoisSuomesta pakomatkalle lähteneet saamelaiset tai lappilaiset. Tässä mielessä teos avaa myös suomalaista historiaa uudella tavalla, ja sijoittaa siihen vielä uudet turvapaikanhakijat.

Kun Lähi-idästä tai Pohjois-Afrikasta paenneiden ihmisten visuaaliset hahmot rinnastuvat elokuvan ääniraidalla luettuihin pohjoissuomalaisten evakoiden muistoihin ja tarinafragmentteihin tarjoutuu mahdollisuus nähdä ja kuulla pakolaisuuden kokemuksen yhtäläisyyksiä - riippumatta siitä mistä, mihin ja milloin paetaan (ks. myös esim. Ahonen 2018, 10). Väitämmekin, että teos saattaa paitsi synnyttää solidaarisuuden tunnetta, jopa muuttaa katsojien käsityksiä "meisyydestä" ja toiseudesta, ja historiakulttuuriin osallisena se voi lisätä ymmärrystä niin kauan sitten kuin äskettäin sotaa paenneiden tilanteista. Toki yhtä lailla teoksen katsominen voi vahvistaa ulossulkevan suomalaisuuden "meisyyttä", jos vailla omaa ääneen kerrottua historiaa esitetyt visuaaliset hahmot jäävätkin etäisiksi "heiksi".

Pakolaisuuden esitykset sukupuolittuvat eri tavoin, ja suomalaiset julkiset keskustelut ovat eri aikoina esittäneet rajoja ylittäneitä miespuolisia maahan tulijoita rodullistettuna seksuaalisena uhkana. They Came in Crowded Boats and 
Trains -elokuvan visuaalisesti esittämiä nuoria miehiä ei seksualisoida, heidät näytetään pikemminkin avuttomina ja avun tarpeessa olevina, mutta myös selviytyjinä, niin vaelluksellaan pohjoisessa maisemassa kuin perillä vastaanottokeskuksessa. Kertojaääni puolestaan todistaa siitä, että myös suomalaisiin evakkomiehiin on Ruotsissa kohdistunut etnistäviä ennakkoluuloja: oletuksia väkivaltaisuudesta tai naisiin kohdistuvasta ahdistelusta. Näin kerronta kääntää peilin kohti suomalaista katsojaa: "meistäkin" on (ollut) olemassa stereotyyppisiä käsityksiä.

Tekijöiden intentiot ovat selkeän poliittiset: Rainio (2016) kirjoittaa, että "tuomalla menneisyyden ja nykyisyyden vuoropuheluun elokuva haluaa taistella historiallista muistinmenetystä vastaan nykyisessä poliittisessa ilmapiirissä ja muistuttaa, että eteemme voi jälleen tulla aika jolloin suomalaiset - ja muut eurooppalaiset - tarvitsevat suojaa ja apua muilta".

Aikatasojen rinnastaminen ja jopa hämmästyttävät yhtäläisyydet pakolaisten kohtaloissa edesauttavat ymmärrystä siitä, että vastaavuuksia ja jatkuvuuksia voi hahmotella esimerkiksi taiteen keinoin. Poliittiset tapahtumat ja pakolaisuuden kontekstit voivat olla hyvin erilaisia, ja myös pakolaisten kertomukset ovat erilaisia keskenään - mutta historiallista tietoa ja myötätuntoa tarvitaan, jotta voidaan vastata pelkoon ja (sosiaalisen median) julkisuudessa esitettäviin uhkakuviin, jotka nekin toistavat tiettyjä historiallisia diskursseja (Ahonen 2018, 17). Rinnastuksista ei kuitenkaan voi vetää suoria johtopäätöksiä ilman hienovaraista analyysiä ja kontekstointia.

Rainion ja Robertsin elokuvassa historiallinen tieto sekä pakolaisuutta historiallisena ja nykypäivän ilmiönä käsittelevä ymmärrys ovat mukana visuaalisina ja tekstuaalisina vivahteina ja viitteinä enemmän kuin aukikirjoitettuina. Elokuvan toteuttaman kerrostuneen pakolaiskuvauksen avulla voidaankin tarkastella ajassa tapahtuvia muutoksia - siinä lomittuvat tutkimustieto, käsitykset, tarinat ja aikalaiskokemukset. Onko pohjoisten ja eteläisten eriaikaisten pakolaisten elämäntilanteiden, kokemusten tai tunteiden välillä samankaltaisuutta, ja millaisia ovat mahdolliset erot? Taideteos ei pyri varsinaisesti vastaamaan näihin kysymyksiin, mutta jo kysymysten herättäminen on tärkeää.

\section{Lähteet}

Ahmed, Sara (2000) Strange Encounters. Lontoo \& New York: Routledge.

Ahonen, Pertti (2018) Europe and refugees: 1938 and 2015-16. Patterns of Prejudice, vol 52: 2-3, 135-148.

Annila, Silja (2015) Suomalainen ruoka ei kelvannut turvapaikanhakijoille - näin maahanmuuttajat syövät kotimaissaan. YLE 2.10.2015. Saatavilla: <https://yle.fi/aihe/artikkeli/2015/10/01/ suomalainen-ruoka-ei-kelvannut-turvanpaikanhakijoille-nain-maahanmuuttajat> (linkki tarkistettu 18.5.2020).

Butler, Judith (2006) Hankala sukupuoli. Feminismi ja identiteetin kumous. (Gender Trouble. Feminism and Subversion of Identity.) Suom. Tuija Pulkkinen ja Leena-Maija Rossi. Helsinki: Gaudeamus.

Etto, Jorma (toim.) (1975) Evakkotaival. Kuvia ja muisteluksia Lapin evakosta 1944-1945. Rovaniemi: Lapin Maakuntaliitto.

Etto, Jorma (1977) Alkusanat. Teoksessa Jorma Etto (toim.) Pohjoinen taikapiiri. Lapin evakkojen maailma 1944-1945. Rovaniemi: Lapin maakuntaliitto, 5.

Grönholm, Pertti \& Sivula, Anna (2010) Mitä meillä on jäljellä? Teoksessa Pertti Grönholm \& Anna Sivula (toim.) Medeiasta pronssisoturiin. Kuka tekee menneestä historiaa? Turku: Turun Historiallinen Yhdistys ry, 11-20. 
Grönholm, Pertti (2010) Muistomerkkejä ja kolaroivia kertomuksia. Vuoden 2007 pronssisoturikiista ja yhteisöjen kulttuuriset työkalut. Teoksessa Pertti Grönholm \& Anna Sivula (toim.) Medeiasta pronssisoturiin. Kuka tekee menneestä historiaa? Turku: Turun Historiallinen Yhdistys ry, 82-109.

Haavisto, Camilla \& Maasilta, Mari (2018) Hidas media myötätunnon herättäjänä. Teoksessa Mari Maasilta \& Kaarina Nikunen (toim.) Pakolaisuus, tunteet ja media. Tampere: Vastapaino, 127-144.

Hautala-Hirvioja, Tuija (2001) Tuli käsky niin outo ja kumma, tuli lähtö kotoa pois. Teoksessa Heikki Annanpalo, Marja Tuominen \& Ritva Tuomaala (toim.) Saatiin tämä vapaus pitää. Tutkija kohtaa rovaniemeläisveteraanin. Rovaniemi: Rovaniemen kaupunki, maalaiskunta ja seurakunta, Lapin yliopiston taiteiden tiedekunta, 264-297.

Helminen, Marja-Liisa (2016) Maahanmuuttajat muistuttavat sukupuolijakaumaltaan suomalaistaustaisia. Tilastokeskus. Saatavilla: $<$ https://www.tilastokeskus.fi/tietotrendit/artikkelit/2016/maahanmuuttajat-muistuttavat-sukupuolijakaumaltaan-suomalaistaustaisia/> (linkki tarkistettu 18.5.2020).

Horsti, Karina (2019) Refugee testimonies enacted: voice and solidarity in media art installations, Popular Communication, 17:2, 125-139.

Huttunen, Laura (2002) Kotona, maanpaossa, matkalla. Kodin merkitykset maahanmuuttajien omaelämäkerroissa. Helsinki: Suomalaisen Kirjallisuuden Seura.

Kalela, Jorma (2010) Historian rakentamisen mieli ja tutkijan valinnat. Teoksessa Pertti Grönholm \& Anna Sivula (toim.) Medeiasta pronssisoturiin. Kuka tekee menneestä historiaa? Turku: Turun Historiallinen Yhdistys ry, 40-59.

Kivikuru, Ullamaija; Maasilta, Mari \& Nikunen, Kaarina (2018) Johdanto. Teoksessa Mari Maasilta \& Kaarina Nikunen (toim.) Pakolaisuus, tunteet ja media. Tampere: Vastapaino, 7-20.

Korte, Paula (2016) Regarding the appropriation of the Pain of Others. Mustekala. Saatavilla: $<$ http://mustekala.info/blogit/regarding-the-appropriation-of-the-pain-of-others/> (linkki tarkistettu 28.5.2020).

Lehtola, Veli-Pekka (2018) "Sielun olisi pitänyt ehtiä mukaan..." Jälleenrakennettu Saamenmaa. Teoksessa Marja Tuominen ja Mervi Löfgren (toim.) Lappi palaa sodasta. Mielen hiljainen jälleenrakennus. Tampere: Vastapaino, 259-282.

Lähteenmäki, Maria (1999) Jänkäjääkäreitä ja parakkipiikoja. Lappilaisten sotakokemuksia 1939-1945. Helsinki: SKS.

Meinander, Henrik (2016) Kansallisen katseen lumo. Teoksessa Antti Blåfield (toim.) Historian käyttö ja väärinkäyttö. Helsinki: Kustannusosakeyhtiö Siltala, 63-77.

Nikunen, Kaarina (2018) Badolato-Kauhava: maantieteellisen mielikuvituksen merkitys pakolaispolitiikassa. Teoksessa Mari Maasilta \& Kaarina Nikunen (toim.) Pakolaisuus, tunteet ja media. Tampere: Vastapaino, 21-47.

Pennonen, Anne-Maria (2020) In Search of Scientific and Artistic Landscapes: Düsseldorf Landspace Painting and Reflections of the Natural Sciences as Seen in the Artworks of Finnish, Norwegian and German Artists. Finnish National Gallery Publications 3. Helsinki: Finnish National Gallery.

Punkari, Pasi (2015) Huono ruoka ja asuinolot saivat kymmenet turvapaikanhakijat kadulle poliisi pelkää asenteiden kovenevan. YLE 30.9.2015. Saatavilla: <https://yle.fi/uutiset/3-8344737> (linkki tarkistettu 18.5.2020).

Pöyhtäri, Reeta (2018) Raiskausuutisista vihapuheeseen: uutismedian eettistä harkintaa. Teoksessa Mari Maasilta \& Kaarina Nikunen (toim.) Pakolaisuus, tunteet ja media. Tampere: Vastapaino, 92-126.

Rainio, Minna (2005) “Se oli niin pyhä se”. Teoksessa Pälvi Rantala \& Marja Tuominen (toim.) Rajoilla. Puheenvuoroja tutkimuksen rajoista ja rajojen tutkimisesta. Rovaniemi: Lapin yliopisto, 99-116.

Rainio, Minna (2015) Globalisaation varjoisat huoneet. Kuulumisen ja ulossulkemisen tilat rajanylityksiä käsittelevissä liikkuvan kuvan installaatioissa. Rovaniemi: Lapin yliopisto.

Rainio, Minna (2016) They came in crowded boats and trains. Matkalla ajassa ja paikassa -hankkeen blogi, 18.10.2016. Saatavilla: <https://ajassajapaikassa.wordpress.com/2016/10/18/ they-came-in-crowded-boats-and-trains/> (linkki tarkistettu 18.5.2020).

Rainio, Minna (2020) Sähköpostiviesti 14.1.2020.

Rossi, Leena-Maija (2010) Sukupuoli ja seksuaalisuus, erosta eroihin. Teoksessa Tuija Saresma, Leena-Maija Rossi \& Tuula Juvonen (toim.) Käsikirja sukupuoleen. Tampere: Vastapaino. 
Rautio, Erkki (2004) Johdanto. Teoksessa Tuomo Korteniemi \& Mirja Vuopio (toim.) Pohjoiset pakolaiset. Tietoa ja tarinoita Lapin sodasta ja lappilaisten evakkotaipaleelta. Tornio: Pohjan Väylä, 9-11.

Saresma, Tuija (2018) Politics of Fear and Racialized Rape: Intersectional Reading of the Kempele Rape Case. Teoksessa Peter Hervik (toim.) Racialization, Racism, and Anti-Racism in the Nordic Countries. Lontoo: Palgrave Macmillan, 63-91.

Sundén, Jenny \& Paasonen, Susanna (2018) Shameless hags and tolerance whores: feminist resistance and affective circuits of online hate. Feminist Media Studies 18: 4, 643-656.

Tuominen, Marja \& Löfgren, Mervi (2018) Esipuhe. Taidetta ja kulttuuria Lapin rauhassa. Teoksessa Marja Tuominen \& Mervi Löfgren (toim.) Lappi palaa sodasta. Mielen hiljainen jälleenrakennus. Tampere: Vastapaino, 25-33.

Urponen, Maija (2010) Mi kaikkien rajojen? Helsingin olympialaiset ja Armi Kuusela kansainvälisyyden kynnyksellä. Helsinki: Suomalaisen Kirjallisuuden Seura.

Viljanen, Kaisa (2016) Taiteilija täytti gallerian pakolaisten Lesbokselle hylkäämillä pelastusliiveillä. Helsingin Sanomat 10.2.2016. Saatavilla: <https://www.hs.fi/kulttuuri/art-2000002885240. html> (linkki tarkistettu 18.5.2020).

Wagner, Hans-Ulrich \& Seuferling, Philipp (2020) Uses of the Past in Refugee Documentaries in Sweden and Germany. Media History, 26:1, 91-104.

Wilson, Paul (2009) Kansallismaisema kansallismaiseman jälkeen - National Landscape After the End of National Landscape. Teoksessa Kari Soinio (2009) Maisemasta paikkaan - From Landscape to Place. Helsinki: Maahenki. 